\title{
Decreased Proteolytic Activity of the Mitochondrial Amyloid- $\beta$ Degrading Enzyme, PreP Peptidasome, in Alzheimer's Disease Brain Mitochondria
}

\author{
Nyosha Alikhani ${ }^{\mathrm{a}, \mathrm{e}, 1}$, Lan Guo ${ }^{\mathrm{a}, 1}$, Shiqiang Yan ${ }^{\mathrm{a}}$, Heng Du ${ }^{\mathrm{a}}$, Catarina Moreira Pinho ${ }^{\mathrm{e}}$, John Xi Chen ${ }^{\mathrm{f}}$, \\ Elzbieta Glaser ${ }^{\mathrm{e}}$ and Shirley ShiDu Yan ${ }^{\mathrm{a}, \mathrm{b}, \mathrm{c}, \mathrm{d}, *}$ \\ a Department of Surgery \\ ${ }^{\mathrm{b}}$ Department of Pathology and Cell Biology, College of Physicians and Surgeons of Columbia University, \\ New York, NY, USA \\ ${ }^{\mathrm{c}}$ Department of Taub Institute for Research on Alzheimer's disease and the Aging Brain, \\ College of Physicians and Surgeons of Columbia University, New York, NY, USA \\ ${ }^{\mathrm{d}}$ Department of Pharmacology and Toxicoogy and Higuchi Bioscience Center, School of Pharmacy, \\ University of Kansas, Lawrence, KS, USA \\ ${ }^{\mathrm{e}}$ Department of Biochemistry and Biophysics, Stockholm University, Stockholm, Sweden \\ ${ }^{\mathrm{f}}$ Department of Neurology, Memorial Sloan-Kettering Cancer Center, New York, NY, USA
}

\begin{abstract}
Accumulation of amyloid- $\beta$ peptide $(A \beta)$, the neurotoxic peptide implicated in the pathogenesis of Alzheimer's disease (AD), has been shown in brain mitochondria of $\mathrm{AD}$ patients and of $\mathrm{AD}$ transgenic mouse models. The presence of $\mathrm{A} \beta$ in mitochondria leads to free radical generation and neuronal stress. Recently, we identified the presequence protease, PreP, localized in the mitochondrial matrix in mammalian mitochondria as the novel mitochondrial A $\beta$-degrading enzyme. In the present study, we examined PreP activity in the mitochondrial matrix of the human brain's temporal lobe, an area of the brain highly susceptible to $A \beta$ accumulation and reactive oxygen species (ROS) production. We found significantly lower hPreP activity in $\mathrm{AD}$ brains compared with non-AD age-matched controls. By contrast, in the cerebellum, a brain region typically spared from $A \beta$ accumulation, there was no significant difference in hPreP activity when comparing AD samples to non-AD controls. We also found significantly reduced PreP activity in the mitochondrial matrix of AD transgenic mouse brains (Tg mA $3 P P$ and $\mathrm{Tg} \mathrm{mA} \beta \mathrm{PP} / \mathrm{ABAD}$ ) when compared to non-transgenic aged-matched mice. Furthermore, mitochondrial fractions isolated from $\mathrm{AD}$ brains and $\mathrm{Tg} \mathrm{mA} \beta \mathrm{PP}$ mice had higher levels of 4-hydroxynonenal, an oxidative product, as compared with those from non-AD and nonTg mice. Accordingly, activity of cytochrome $\mathrm{c}$ oxidase was significantly reduced in the AD mitochondria. These findings suggest that decreased PreP proteolytic activity, possibly due to enhanced ROS production, contributes to A $\beta$ accumulation in mitochondria leading to the mitochondrial toxicity and neuronal death that is exacerbated in AD. Clearance of mitochondrial $\mathrm{A} \beta$ by PreP may thus be of importance in the pathology of $\mathrm{AD}$.
\end{abstract}

Keywords: Mitochondrial amyloid- $\beta$, mitochondrial function, oxidative stress, presequence protease (PreP), proteolysis

\footnotetext{
1 These authors contributed equally to this work.

*Correspondence to: Shirley ShiDu Yan, Department of Pharmacology and Toxicology, Higuchi Bioscience Center School of Pharmacy, University of Kansas, 2099 Constant Avenue, Lawrence, KS 66047, USA. Tel.: +1 785864 3637; E-mail: shidu@ku.edu.
}

\section{INTRODUCTION}

Accumulation of amyloid- $\beta$ peptide $(A \beta)$ is a hallmark of Alzheimer's disease (AD) according to the amyloid cascade hypothesis, and is produced by regulated intramembrane proteolysis of the amyloid- $\beta$ 
protein precursor $(\mathrm{A} \beta \mathrm{PP})$ via sequential cleavage by $\beta$ - and $\gamma$-secretases $[1,2]$. Extracellular accumulation of $\mathrm{A} \beta$ in the form of senile plaques has been detected in individuals with $\mathrm{AD}[3,4]$. It is also known that there is a reduction of mitochondrial volume during early stage $\mathrm{AD}$, and this fact has led to an increased focus on intracellular events, especially the role of mitochondria, in $\mathrm{AD}$ [5-7]. $\mathrm{A} \beta$ peptides have been found in mitochondria of the AD brains as well as in $\mathrm{AD}$ transgenic mice overexpressing $\mathrm{A} \beta$ [8-14]. Accumulation of mitochondrial $A \beta$ has been shown at a young age in AD transgenic mice, before extracellular plaques are formed $[8,9]$. Notably, mitochondrial A $\beta$ accumulation significantly correlates to the abnormal mitochondrial function as shown by impaired mitochondrial respiratory function, inactivated mitochondrial respiratory key enzyme, and reduced ATP levels [8-13, 15-17].

A $\beta P P$ binds to mitochondria and is incompletely translocated leaving the $A \beta$ region outside the mitochondrial membrane [18-20], suggesting that $A \beta$ cannot be produced inside the mitochondria. We have recently shown in vitro that $\mathrm{A} \beta$ is transported into mitochondria via the protein Translocase of the Outer Membrane (TOM) machinery [14]. The cell surface RAGE receptor (receptor for advanced glycation end product) also contributes to transport of $A \beta$ from the cell surface to the intracellular space including mitochondrial localization. RAGE-deficient neurons displayed a decrease in uptake of $A \beta$ and protection from $A \beta$-induced mitochondrial dysfunction [21]. Further, $A \beta$-targeted mitochondrial proteins, ABAD (A $\beta-$ binding alcohol dehydrogenase) and cyclophilin $\mathrm{D}$, are upregulated in neurons of $\mathrm{AD}$ patients and $\mathrm{AD}$ transgenic mice $[10,12,13,15,22,23]$. Interaction of $\mathrm{A} \beta$ with $\mathrm{ABAD}$ in $\mathrm{AD}$ mitochondria leads to elevated reactive oxygen species (ROS) in neurons and neuronal death [10, 24-26]. The abrogation of cyclophilin $\mathrm{D}$ in $\mathrm{A} \beta$-rich mitochondria attenuates mitochondrial ROS accumulation/production and protects against aberrant mitochondrial and neuronal function.

A few years ago, we identified a novel mitochondrial peptidasome, the presequence protease (PreP), that is responsible for $A \beta$ degradation in mitochondria [27, 28]. PreP is a metallopeptidase, localized in the mitochondrial matrix in mammals, containing an inverted zinc-binding motif. It belongs to the pitrilysin oligopeptidase family (M16C), which also includes insulin degrading enzyme (IDE), implicated in AD [29-31]. PreP was originally identified as a protease degrading mitochondrial presequences [32], but has also been shown to degrade other unstruc- tured peptides up to 70 amino acid residues in length $[33,34]$, including $A \beta$. We have characterized the human PreP homologue (hPreP) in brain mitochondria and shown its capacity to degrade the $A \beta$ peptides including $A \beta_{1-40}, A \beta_{1-42}$, and Arctic $A \beta$. Immunoinactivation studies in human brain mitochondria using hPreP antibodies showed complete inhibition of proteolytic activity against $A \beta$, demonstrating that hPreP is the protease responsible for degradation of this toxic peptide [27]. However, it has not yet been proven whether PreP activity is relevant to amyloid pathology and mitochondrial $A \beta$ accumulation and whether its activity is altered in an $A \beta$-rich environment, such as in the AD brain and AD mouse models.

Molecular homology modeling of hPreP based on the crystal structure of Arabidopsis thaliana PreP, AtPreP, refined at $2.1 \AA$ [35], revealed four topologically similar domains creating two halves, connected by a hinge region. These two halves enclose a large chamber wherein the proteolytic activity occurs. This molecular modeling was followed by the identification of $\mathrm{Cys}^{90}$ in the first domain and $\mathrm{Cys}^{527}$ at the hinge region that together form a disulfide bridge (under oxidizing conditions) resulting in a complete inhibition of the enzyme.

In the present study, we investigated the alterations of hPreP activity in AD individuals and transgenic AD mouse models. We studied hPreP activity in human brain (temporal lobe) mitochondrial matrix from $\mathrm{AD}$ individuals and in non-AD age-matched controls. We also investigated hPreP activity in the AD spared region, the cerebellum, which is usually free from $\mathrm{A} \beta$ accumulation. In an AD transgenic mouse model, we compared PreP activity overexpressing $\mathrm{mA} \beta \mathrm{PP} /$ $\mathrm{A} \beta$ and $\mathrm{mA} \beta \mathrm{PP} / \mathrm{ABAD}$ at different ages to agedmatched non-transgenic littermates. The selected AD mouse models were well-suited to our strategy for determining whether enhancing/accelerating $A \beta$ accumulation and oxidative stress in mitochondria alter PreP expression/activity since these animals have been characterized with respect to mitochondrial $A \beta$ accumulation, mitochondrial and neuronal function, and neuropathological and behavioral endpoints $[8-10,12$, $13,26,51]$.

\section{MATERIALS AND METHODS}

\section{Human brain samples and transgenic $(T g)$ mice}

Human brain tissues of temporal lobe and cerebellum from individuals with $\mathrm{AD}$ and age-matched non-AD controls were obtained from the New York 
Brain Bank at Columbia University (Table 1). The following Tg mice were used in these studies: $\mathrm{Tg} \mathrm{mA} \beta \mathrm{PP}$ overexpressing human mutant form of amyloid- $\beta$ protein precursor (mA $\beta P P, J-20$ line) and $A \beta, T g$ ABAD mice overexpressing neuronal ABAD driven by PDGF-B chain promoter, Tg $\mathrm{mA} \beta \mathrm{PP} / \mathrm{ABAD}$ mice overexpressing both mutant human form of $A \beta P P$ and $\mathrm{ABAD}$, and non-transgenic littermate controls (nonTg) [8-10, 12, 13, 37, 51]. Animal studies were approved by the Animal Care and Use Committee of Columbia University in accordance with the National Institute of Health guidelines for animal care.

\section{Isolation of mitochondria}

Human and mice brain mitochondria were isolated using Percoll gradient as described previously $[8,12]$. Briefly, human temporal lobe, human cerebellum and cerebral lobe from mice brain were minced with scissors and washed two times with isolation buffer (225 mM mannitol, $75 \mathrm{mM}$ sucrose, $1 \mathrm{mM}$ EGTA, $5 \mathrm{mM}$ HEPES, and $1 \mathrm{mg} / \mathrm{ml}$ bovine serum albumin [BSA], pH 7.2) to remove contaminating blood, followed by homogenization in a glass Teflon homogenizer in $14 \mathrm{ml}$ isolation buffer. Homogenates were then centrifuged at $1500 \mathrm{~g}$ for $5 \mathrm{~min}$. Supernatant was applied to $14 \%$ Percoll and centrifuged at $12,000 \mathrm{~g}$ for $10 \mathrm{~min}$. The mitochondrial pellets were re-suspended and centrifuged at $8000 \mathrm{~g}$ for $10 \mathrm{~min}$ followed by a washing and re-suspension in $100 \mu l$ sonication buffer (20 mM HEPES-KOH, $10 \mathrm{mM} \mathrm{MgCl}_{2}$, pH 7.5). Protein concentration was determined by Bio-Rad protein concentration kit with BSA as standard.

\section{Preparation of brain mitochondria matrix}

Isolated brain mitochondria were diluted with a sonication buffer to a final concentration of $8 \mu \mathrm{g} / \mu \mathrm{l}$ and incubated $30 \mathrm{~min}$ at $4{ }^{\circ} \mathrm{C}$ followed by sonication $4 \times 30$ s. To obtain the matrix fraction, samples were then centrifuged at 70,000 rpm for $1 \mathrm{~h}$ and the supernatant containing the matrix proteins was used in the PreP degradation assay studies.

\section{PreP expression levels}

$20 \mu \mathrm{g}$ of the isolated human and mice brain mitochondrial matrix were subjected to a $12 \%$ Bis-Tris gel (Invitrogen, CA), run in $1 \times$ MES buffer, and transferred to nitrocellulose membrane Hybond ${ }^{\mathrm{TM}}$ (Amersham Biosceinece) for $1 \mathrm{~h}$ at $100 \mathrm{~V}$. The membrane was blocked overnight in 5\% milk-PBS. For detection of PreP, antibodies against hPreP were applied at a dilution of [1:1500-2000] for $1 \mathrm{~h}$ followed by detection with horseradish peroxidase-conjugated anti-rabbit secondary antibody (1:2500) and ECL (GE Healthcare). Hsp60 expression levels were detected by antibody raised against Hsp60, 1:2000 for $1 \mathrm{~h}$ followed by detection with horseradish peroxidase-conjugated anti-mouse secondary antibody (1:2500) and ECL (GE Healthcare).

\section{Degradation assays}

The degradation assay for studying proteolytic activity of hPreP in human brain mitochondrial matrix fractions was conducted by using $20 \mu \mathrm{g}$ isolated matrix protein and the following substrates: $0.25 \mu \mathrm{g} \mathrm{pF}_{1} \beta$, a mitochondrial presequence derived from the $F_{1} \beta$ subunit of the Nicotiana plumbaginifolia ATP synthase $\mathrm{N}_{5.7} \mathrm{pF}_{1} \beta(2-54)$ [36], $0.25 \mu \mathrm{g}$ Biotin-labeled $\mathrm{A} \beta_{1-40}$ and $0.25 \mu \mathrm{g}$ Biotin-labeled $A \beta_{1-42}$ in a degradation

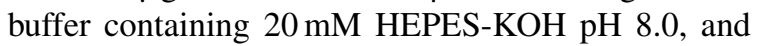
$10 \mathrm{mM} \mathrm{MgCl}_{2}$. For inhibitory studies, $20 \mathrm{mM}$ orthophenathroline $(\mathrm{oPh})$ was pre-incubated with $20 \mu \mathrm{g}$ of brain mitochondrial matrix protein on ice for 10 min before the addition of substrate. For studies of PreP activity under oxidized conditions, $20 \mu \mathrm{g}$ matrix protein was pre-incubated with $0.1 \mathrm{mM}$ and $1 \mathrm{mM}$ $\mathrm{K}_{3} \mathrm{Fe}(\mathrm{CN})_{6}$ for $10 \mathrm{~min}$ on ice before addition of $1 \mu \mathrm{g}$ $\mathrm{A} \beta_{1-40}$. The immuno-inactivation was performed by pre-incubating mitochondrial fractions with $6 \mu \mathrm{g}$ of antibodies raised against hPreP or $18 \mu \mathrm{g}$ of antibodies raised against the presequence of $F_{1} \beta$ subunit of the ATP synthase from $N$. plumbaginifolia, $\mathrm{pF}_{1} \beta$ at $4^{\circ} \mathrm{C}$ for $30 \mathrm{~min}$ before the addition of Biotin-labeled $\mathrm{A} \beta_{1-40}$. Samples were incubated for $2.5 \mathrm{~h}$ at $37^{\circ} \mathrm{C}$. Reactions were stopped by the addition of $2 \times$ sample buffer, analyzed on NuPAGE $12 \%$ Bis-Tris gel (Invitrogen, $\mathrm{CA}$ ), and run in $1 \times$ MES buffer. Proteins were electrophoretically transferred to nitrocellulose membrane Hybond ${ }^{\mathrm{TM}}$ (Amersham Bioscience) for $1 \mathrm{~h}$ at $100 \mathrm{~V}$. For $\mathrm{pF}_{1} \beta$ identification, the nitrocellulose membrane was blocked overnight in 5\% milk-PBS followed by incubation with $\mathrm{pF}_{1} \beta$ antibody (1:2000) and detection with horseradish peroxidase-conjugated anti-rabbit secondary antibody (1:2500) and ECL (GE Healthcare). For analyzing the degradation of Biotin labeled $A \beta_{1-40}$ and Biotin labeled $A \beta_{1-42}$ (BiotinLC- $A \beta_{1-40}$, Biotin-LC- $\left.A \beta_{1-42}\right)$, the nitrocellulose membrane was dried overnight at $25^{\circ} \mathrm{C}$ followed by blocking with $2 \%$ milk-PBS for $1 \mathrm{~h}$. Immunoblotting was performed with ExtraAvidin Peroxidase Conjugate 1:3000 (Sigma) and detection with ECL. 


\section{Measurement of HNE in brain mitochondrial fractions}

Brain mitochondria isolated from human subjects and $\mathrm{Tg}$ mice were sonicated in the cold isolation buffer, then centrifuged at $10,000 \mathrm{~g}$ for 10 minutes at $4{ }^{\circ} \mathrm{C}$. Levels of 4-hydroxynonenal (HNE) were measured using commercial ELISA Kit (Cell Biolabs, Inc.).

\section{Measurement of cytochrome c oxidase activity}

Cytochrome c oxidase activity in the cortical mitochondria from $\mathrm{AD}$ and non-AD temporal pole and cerebellum was measured as previously described $[12,13]$.

\section{Statistical analysis}

Quantification analysis was performed by using NIH Image J software. Statistical analyses were performed using STATVIEW software. One-way ANOVA was used for repeated measures followed by Fisher's Protected Least Significant Difference for post-hoc comparisons. Results are expressed as mean \pm Standard Error Mean (SEM). $p<0.05$ was considered significant.

\section{RESULTS}

\section{Decreased PreP proteolytic activity in AD brain mitochondria}

It is well established that the temporal lobe is one of the most highly susceptible regions to the $A \beta$ accumulation in the $\mathrm{AD}$ brain, whereas $\mathrm{A} \beta$ accumulation and aggregation are usually not found in the cerebellum. Therefore, we investigated hPreP activity in AD brain mitochondrial matrix fractions from these two areas of the brain and compared such activity to age-matched non-AD individuals. Measurement of PreP proteolytic activity in $\mathrm{AD}$ and $\mathrm{mA} \beta \mathrm{PP}$ brain mitochondria was based on the capacity of PreP in the mitochondrial matrix for degrading exogenous biotin-labeled $A \beta$ $\left(A \beta_{40}\right.$ or $\left.A \beta_{42}\right)$ or non- $A \beta$ peptide $\left(F_{1} \beta\right.$ presequence, $\mathrm{pF}_{1} \beta$ ). The amount of $\mathrm{A} \beta$ or $\mathrm{pF}_{1} \beta$ peptides degraded by PreP from AD brains or A $\beta$ PP mice compared to those from non-AD or nonTg mice was representative of changes in PreP activity. We isolated brain mitochondrial matrix proteins from the temporal lobes and cerebella of $12 \mathrm{AD}$ patients and 8 control patients (Table 1). The isolated human brain mitochondrial fraction showed proteolytic activity against biotin- labeled $A \beta_{1-40}, A \beta_{1-42}$, and $\mathrm{pF}_{1} \beta$ (Fig. 1A-C). There was a significant reduction in proteolytic activity of $\mathrm{hPreP}$ in the mitochondrial matrix extracted from temporal lobes of AD patients compared with age-matched non-AD individuals for all three substrates [biotinlabeled $\mathrm{A} \beta_{1-40}(p=0.0156)$, biotin-labeled $\mathrm{A} \beta_{1-42}$ $(p=0.02)$, and $\left.\mathrm{pF}_{1} \beta(p=0.0136)\right]$ (Fig. 1A-C).

To determine the effect of PreP proteolytic activity, ortho-phenantroline ( $\mathrm{OPh})$, a metalloprotease inhibitor, was used for the inhibition study in the degradation assay. The degradation activity of PreP was completely abolished in the presence of oPh (Fig. 1D). The strong immunoreactive biotin $\mathrm{A} \beta$ or $\mathrm{pF}_{1} \beta$ bands were noticeable due to the loss of PreP proteolytic activity in the presence of oPh inhibitor (Fig. 1D, lanes 3 and 7 for degrading $A \beta$ and Fig. $2 \mathrm{D}$, lane 3 for degrading $\mathrm{pF}_{1} \beta$ ), as compared to those without oPh treatment (Figs. 1D and 2D, lane 2).

To determine the PreP-dependent degradation of $A \beta$, we performed the following two experiments as shown in Fig. 1D: 1) immuno-inactivation assay with a specific antibody against PreP; and, 2) immunoinactivation assay with unrelated control antibody, such as a specific antibody to the $F_{1} \beta$ presequence, which is a non- $A \beta$ substrate for PreP. In the absence of PreP antibody, mitochondrial matrix PreP completely degraded biotin-labeled $A \beta$ (Fig. 1D, lanes 2 and 6). By contrast, neutralization of mitochondrial matrix PreP protein with PreP antibody revealed an almost complete inhibition of the degradation of biotinlabeled $A \beta_{1-40}$ (Fig. 1D, lanes 4 and 8 ) as demonstrated by $A \beta$ immunoreactive bands, whereas no effect on PreP proteolytic activity for degrading $A \beta$ was seen in the presence of $\mathrm{pF}_{1} \beta$ antibodies, in which no $\mathrm{A} \beta$ immunoreactive bands were observed (Fig. 1D, lanes 5 and 9). These results verified that $\mathrm{hPreP}$ is the protease responsible for degrading these two different peptides $\left(\mathrm{A} \beta\right.$ and $\left.\mathrm{pF}_{1} \beta\right)$ in isolated human brain mitochondrial matrix and that these in vitro degradation assays can be used to study proteolytic activity in human and mouse brain mitochondrial matrix.

To determine whether reduced activity of hPreP in the mitochondrial matrix fraction extracted from temporal lobes of $\mathrm{AD}$ patients was due to lower protein expression of hPreP, we performed Western blot analysis of mitochondrial fractions using specific antibody to $\mathrm{hPreP}$. Statistical analysis of intensity of immunoreactive hPreP bands normalized to Hsp60 (mitochondrial protein marker) revealed a slight $(11 \%)$ but not significant decrease in relative expression levels of hPreP in the temporal lobe of $\mathrm{AD}$ individuals compared to age-matched non-AD subjects (Fig. 1E). 
Table 1

The information on the human brain tissues used in the experiments

\begin{tabular}{|c|c|c|c|c|c|c|}
\hline Case & Gender & Age (yr) & PMI (h) & Braak stage & $\begin{array}{l}\text { Neuritic plaques - } \\
\text { Temporal pole }\end{array}$ & $\begin{array}{c}\text { Neuritic plaques - } \\
\text { Hippocampus }\end{array}$ \\
\hline AD1 & M & 86 & 4.4 & $\mathrm{VI} / \mathrm{VI}$ & $\begin{array}{l}25-30 \text { per } 100 \times \\
\text { microscope field }\end{array}$ & Rare \\
\hline $\mathrm{AD} 2$ & $\mathrm{~F}$ & 89 & 3.3 & $\mathrm{VI} / \mathrm{VI}$ & $\begin{array}{l}10-15 \text { per } 100 \times \\
\text { microscope field }\end{array}$ & Rare \\
\hline $\mathrm{AD} 3$ & $\mathrm{~F}$ & 89 & 13.6 & $\mathrm{VI} / \mathrm{VI}$ & $\begin{array}{l}10-20 \text { per } 100 \times \\
\text { microscope field }\end{array}$ & Occasional \\
\hline $\mathrm{AD} 4$ & $\mathrm{~F}$ & 81 & 2.5 & $\mathrm{VI} / \mathrm{VI}$ & $\begin{array}{l}\text { Up to } 30 \text { per } 100 \times \\
\text { microscope field }\end{array}$ & Many \\
\hline AD5 & $\mathrm{F}$ & 89 & 5.5 & $\mathrm{VI} / \mathrm{VI}$ & $\begin{array}{l}\text { Up to } 30 \text { per } 100 \times \\
\text { microscope field }\end{array}$ & Many \\
\hline AD6 & $\mathrm{F}$ & 89 & 13.8 & VI/VI & $\begin{array}{l}\text { Up to } 10 \text { per } 100 \times \\
\text { microscope field }\end{array}$ & $\begin{array}{l}\text { Up to } 6 \text { per } 100 \times \\
\text { microscope field }\end{array}$ \\
\hline AD7 & $\mathrm{F}$ & 83 & NA & $\mathrm{V} / \mathrm{V}$ & Severe & $\begin{array}{l}\text { Up to } 20 \text { per } 100 \times \\
\text { microscope field }\end{array}$ \\
\hline AD8 & M & 75 & 8.3 & III/III & Severe & $\begin{array}{l}\text { Up to } 20 \text { per } 100 \times \\
\text { microscope field }\end{array}$ \\
\hline AD9 & M & 72 & 2.3 & $\mathrm{VI} / \mathrm{VI}$ & Severe & $\begin{array}{l}\text { Up to } 20 \text { per } 100 \times \\
\text { microscope field }\end{array}$ \\
\hline AD10 & $\mathrm{F}$ & 89 & 3.5 & $\mathrm{VI} / \mathrm{VI}$ & Many & $\begin{array}{l}\text { Up to } 20 \text { per } 100 \times \\
\text { microscope field }\end{array}$ \\
\hline AD11 & $\mathrm{F}$ & 89 & 6.7 & VI/VI & $\begin{array}{l}\text { Up to } 25 \text { per } 100 \times \\
\text { microscope field }\end{array}$ & Present \\
\hline AD12 & $\mathrm{F}$ & 89 & 4.2 & $\mathrm{VI} / \mathrm{VI}$ & $\begin{array}{l}\text { Up to } 30 \text { per } 100 \times \\
\text { microscope field }\end{array}$ & $\begin{array}{l}\text { Up to } 15 \text { per } 100 \times \\
\text { microscope field }\end{array}$ \\
\hline Mean \pm SE & $9 \mathrm{~F} / 3 \mathrm{M}$ & $85 \pm 1.75$ & $6.19 \pm 1.24$ & & & \\
\hline ND1 & M & 89 & 4.9 & $\mathrm{II} / \mathrm{II}$ & Very rare & Very rare \\
\hline ND2 & M & 74 & 4.3 & $\mathrm{II} / 0$ & Absent & Absent \\
\hline ND3 & $\mathrm{F}$ & 67 & 5 & 0 & Absent & Absent \\
\hline ND4 & M & 62 & 4.3 & 0 & Absent & Absent \\
\hline ND5 & M & 87 & 5.2 & $\mathrm{III} / \mathrm{I}$ & Absent & Absent \\
\hline ND6 & $\mathrm{F}$ & 76 & 3.6 & $0 / \mathrm{I}$ & Absent & Absent \\
\hline ND7 & M & 89 & 3 & $\mathrm{I} / \mathrm{I}$ & Absent & Absent \\
\hline NAD8 & F & 74 & 18.7 & $\mathrm{II} / 0$ & Absent & Absent \\
\hline Mean \pm SE & $3 \mathrm{~F} / 5 \mathrm{M}$ & $77.25 \pm 3.61$ & $6.13 \pm 1.81$ & & & \\
\hline
\end{tabular}

AD, Alzheimer's disease; ND, non-Alzheimer disease; F, female; M, male; PMI, postmortem interval; SE, standard error.

When comparing degradation activity of hPreP in the cerebella of $\mathrm{AD}$ and non-demented individuals, there was a trend toward lower (but not significantly lower) proteolytic activity of hPreP in this part of $\mathrm{AD}$ human brains against biotin-labeled $\mathrm{A} \beta_{1-40}$ $(p=0.185)$, biotin-labeled $\mathrm{A} \beta_{1-42} \quad(p=0.230)$, and $\mathrm{pF}_{1} \beta(p=0.312)$ (Fig. $\left.2 \mathrm{~A}-\mathrm{C}\right)$. One likely explanation for these findings might be the fact that there is a lack of, or at least lower, levels of $A \beta$ accumulation in the cerebellum, less toxicity in the form of elevated ROS production (Fig. 6B), and therefore less inhibition of hPreP activity. Proteolytic activity of $\mathrm{hPreP}$ was completely abolished in the presence of $\mathrm{OPh}$ (Fig. 1D lanes 3 and 7, Figs. 2D and 3D, lanes 3). Comparison of hPreP expression levels in the cerebellum mitochondrial matrix of $\mathrm{AD}$ and non-AD individuals revealed no significant change in $\mathrm{hPreP}$ protein levels (Fig. 2E). We also examined whether PreP is able to degrade the reversed $A \beta$ peptide $\left(A \beta_{40-1}\right)$. Incubation of $A \beta_{40-1}$ with the recombinant hPreP protein revealed that the enzyme is able to degrade $A \beta_{40-1}$ and that the proteolytic activity is totally inhibited by $20 \mathrm{mM}$ orthophenanthroline $(\mathrm{oPh})$, a metalloprotease inhibitor (data not shown).

\section{Decreased PreP proteolytic activity in transgenic AD mice}

Since cellular and mitochondrial integrity might be deteriorated significantly soon after death and the accompanying tissue disruption might allow potentially non-physiological effects to occur, we studied the mitochondria isolated from cerebral cortices of transgenic AD mice where sample quality was carefully controlled. Tg mA $\beta P P$ mice overexpressing A $\beta P P / A \beta$ have been well characterized in terms of AD-type 
A

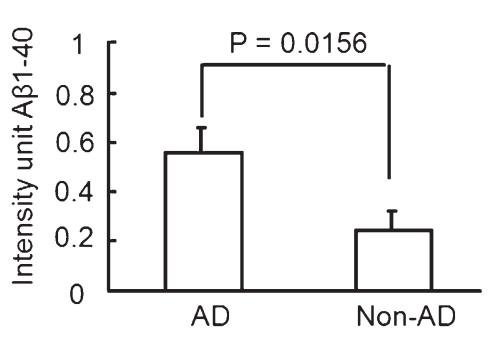

D
B

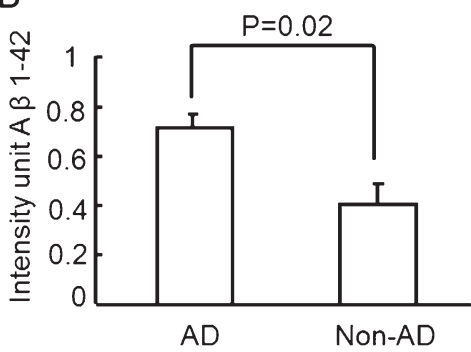

C

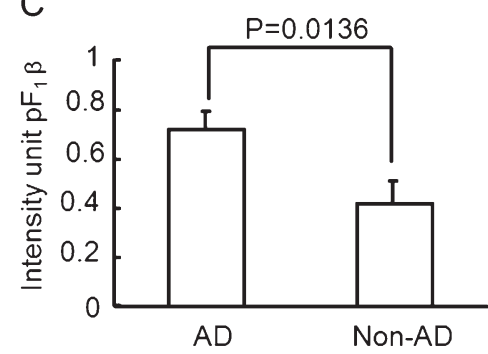

$\mathrm{E}$

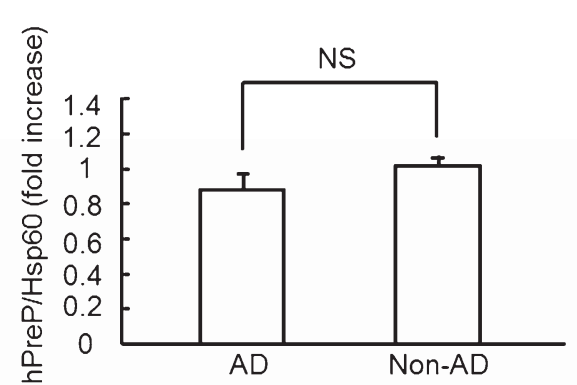

Anti-pF $\beta$

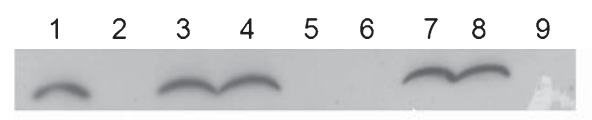

$\mathrm{MA}-{ }_{-}++++++$

oPh

Anti-hPreP

$A \beta 1-40$

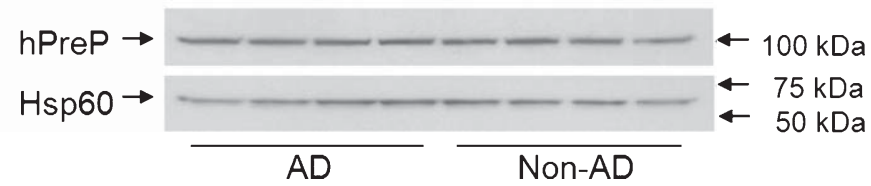

Fig. 1. Changes in $h$ PreP activity/expression in brain mitochondria of $A D$ temporal lobe. Degradation of biotin- $A \beta(A, B)$ and $F_{1} \beta$ presequence peptide $(\mathrm{C})$. hPreP proteins extracted from the cortical mitochondria of the indicated AD and non-AD brains (A, B) were incubated with biotin-labeled $\mathrm{A} \beta(0.25 \mu \mathrm{g})$, and then subjected to immunoblotting with Extravidin peroxidase conjugated IgG and detection with ECL to reveal immunoreactive biotin $\mathrm{A} \beta$. C) For degradation of $\mathrm{F}_{1} \beta$ substrate, mitochondrial hPreP proteins were incubated with $\mathrm{pF} \mathrm{F}_{1} \beta$ followed by the immunoblot with antibody to $\mathrm{pF}_{1} \beta$. Densitometry of the combined immunoreactive $\mathrm{A} \beta(\mathrm{A}, \mathrm{B})$ or $\mathrm{F}_{1} \beta$ bands $(\mathrm{C})$ using NIH Image program is shown. D) Determination of hPreP proteolytic activity and hPreP-dependent degradation of A $\beta$ in brain mitochondrial fraction. Biotin-labeled $A \beta$ was completely degraded by the isolated human mitochondrial matrix hPreP protein (MA-hPreP) (lanes 2 and 6). The oPh (ortho-phenantroline, an inhibitor of PreP proteolytic activity) blocked the degradation of biotin A $\beta$ (lanes 3 and 7). The immuno-inactivation assay confirmed hPrePinduced degradation of $\mathrm{A} \beta$. When isolated human mitochondrial matrix hPreP protein (MA-hPreP) was pre-incubated with antibody against hPreP, degradation of $A \beta_{1-40}$ (lane $4 \& 8$ ) was almost completely inhibited, whereas incubation of $\mathrm{pF}_{1} \beta$ presequence antibodies did not affect $\mathrm{A} \beta$ degradation (lanes 5 and 9). E) Immunoblotting of brain mitochondria from AD and non-AD brains for hPreP. The upper panel denotes representative immunoblots for human PreP and Hsp60. Hsp60 was used as a mitochondrial marker and protein loading controls. The lower panel shows densitometry of hPreP immunoreactive bands from the indicated brain mitochondria. NS: no statistical significance between these groups $(p>0.05)$. Mitochondria were isolated from 12 AD brains and 8 non-AD brains. All experiments were performed in triplicates.

functional, neuropathological, behavioral and electrophysiological changes [8-10, 12, 26, 37, 38]. Notably, accumulation of mitochondrial $\mathrm{A} \beta$ occurs as early as 4 months of age [8] before the onset of $A \beta$ pathology and is associated with mitochondrial abnormalities [8-10, 26]. Furthermore, previous studies have shown that transgenic mice overexpressing $\mathrm{mA} \beta \mathrm{PP}$ and $\mathrm{ABAD}$ (Tg $\mathrm{mA} \beta \mathrm{PP} / \mathrm{ABAD}$ ) manifested excessive production of reactive free radicals, as well as aberrant mitochondrial and neuronal function $[8,10,26]$. Therefore, we investigated proteolytic activity of PreP in $\mathrm{Tg}$ mA $\beta P$ /ABAD mice (accelerated AD model) as well as in $\mathrm{Tg} \mathrm{mA \beta PP}$ mice and compared the results to $\mathrm{Tg}$ ABAD mice and nonTg littermate controls.
First, proteolytic activity of PreP against all the three substrates was significantly reduced in the cortical mitochondrial matrix isolated from 5-months-old Tg mAßPP mice compared to nonTg littermate cortical mitochondria: $\mathrm{A} \beta_{1-40}(p=0.02), \mathrm{A} \beta_{1-42}(p=0.04)$, and $\mathrm{pF}_{1} \beta(p=0.04)$ (Fig. 3A-C). Second, the activity in Tg mAßPP/ABAD mice was significantly lower than that in both nonTg mice $\left(\mathrm{A} \beta_{1-40}, p=0.007 ; \mathrm{A} \beta_{1-42}\right.$, $p=0.008$; and $\left.\mathrm{pF}_{1} \beta, p=0.002\right)$ and $\mathrm{Tg} \mathrm{mA} \beta \mathrm{PP}$ mice $(p<0.05)$. Notably, compared to nonTg cortical mitochondria, PreP activity for degrading A $\beta$ (Fig. 3A-B) was decreased by 2.3- and 3.8-fold in $\mathrm{mA \beta PP}$ and $\mathrm{mA} \beta \mathrm{PP} / \mathrm{ABAD}$ mitochondria, respectively; these data suggest that increased expression of $\mathrm{ABAD}$ in an 
A

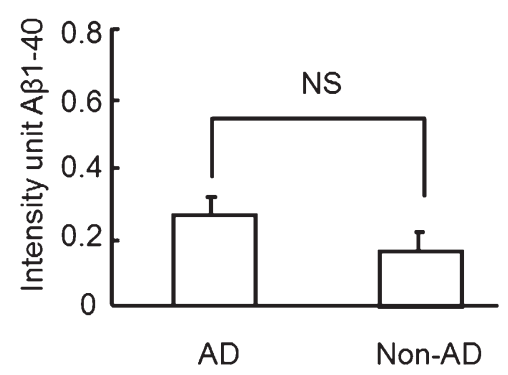

D

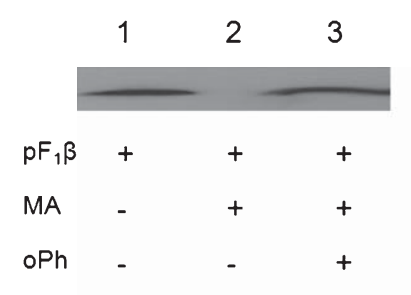

B

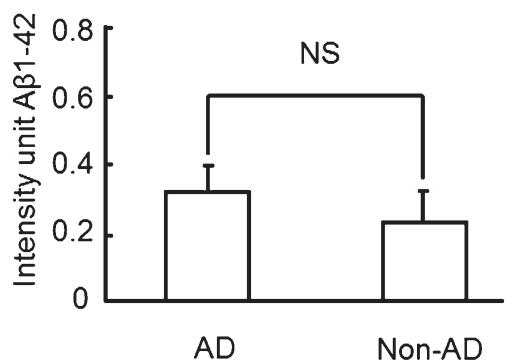

E
C

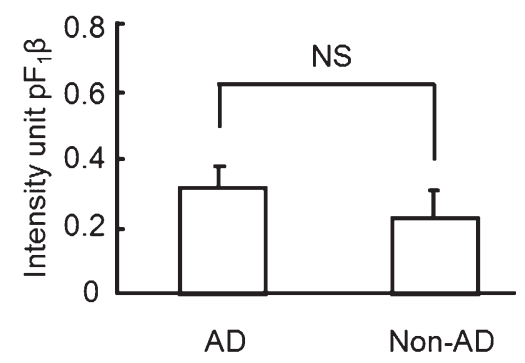

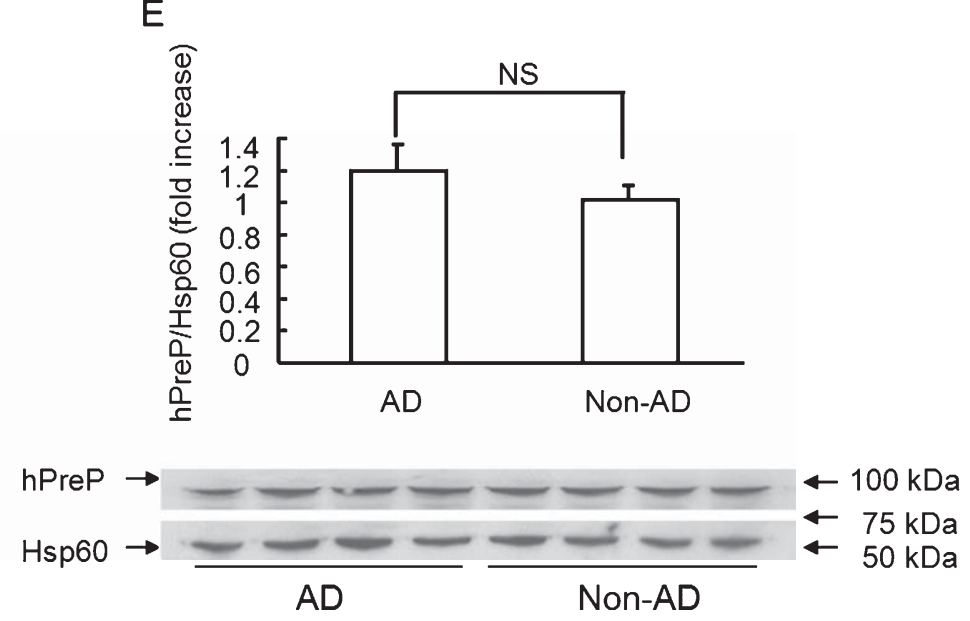

Fig. 2. hPreP activity/expression in the cerebellum of AD and non-AD brains. Mitochondrial hPreP extracted from cerebellum for degrading biotin $A \beta_{40 / 42}(A, B)$ and $\mathrm{pF}_{1} \beta(\mathrm{C})$. Densitometry of $\mathrm{A} \beta$ or $\mathrm{pF}_{1} \beta$ immunoreactive bands are shown by diagram bars. D) Effect of hPreP activity on degrading of $\mathrm{F}_{1} \beta$ presequence $\left(\mathrm{pF}_{1} \beta\right) \cdot \mathrm{pF}_{1} \beta$ was completely degraded by mitochondrial matrix hPreP protein $\left(\mathrm{MA}-\mathrm{hPreP}\right.$, no $\mathrm{F}_{1} \beta$ immunreactive band in lane 2 versus $\mathrm{F}_{1} \beta$ immunoreactive band in lane 1 without MA-hPreP). In the presence of oPh, MA-PreP was not able to degrade $\mathrm{pF}_{1} \beta$ (lane 3 versus lane 2 without $\mathrm{oPh}$ ). E) Immunoblotting of cortical mitochondria from AD and non-AD cerebellum for human PreP. NS: no significant difference. Mitochondria were isolated from 12 AD brains and 8 non-AD brains. All experiments were performed in triplicates.

A $\beta$-rich environment significantly diminishes PreP proteolytic activity. Similarly, PreP activity for degrading $\mathrm{pF}_{1} \beta$ was also diminished by 3.8 - and 7.5-fold in $\mathrm{mA} \beta P P$ and $\mathrm{mA} \beta P P / A B A D$ mitochondria in comparison to the results from nonTg mitochondria (Fig. $3 \mathrm{C}$ ). The PreP activity against $\mathrm{pF}_{1} \beta$ was inhibited in the presence of oPh (Fig. 3D). Third, PreP in the brain cortex mitochondrial matrix isolated from twelvemonth-old Tg mAßPP/ABAD mice was less active in its ability to degrade $A \beta_{1-40}(p=0.004), A \beta_{1-42}$ $(p=0.002)$, and $\mathrm{pF}_{1} \beta(p=0.003)$ compared to agematched nonTg mice (Fig 4A-C). The ability of PreP to degrade these three peptides was also significantly reduced in Tg mA $\beta P P$ mouse brain cortex mitochondrial matrix compared to nonTg mice of the same age $\left(A \beta_{1-40}(p=0.004), A \beta_{1-42}(p=0.002)\right.$, and $\mathrm{pF}_{1} \beta$ $(p=0.007))$ (Fig. 4A-C). We did not find a significant difference of PreP activity between $\mathrm{mA} \beta \mathrm{PP}$ and
$\mathrm{mA} \beta \mathrm{PP} / \mathrm{ABAD}$ at 12 month old mice as compared with those of 5 month old mice. ABAD is a co-factor for exacerbating mitochondrial and neuronal dysfunction, in particular early stage of Alzheimer's disease. Previously, we have demonstrated that neuronal overexpression of $\mathrm{ABAD}$ in $\mathrm{mA} \beta \mathrm{PP}$ mice had early deficits in mitochondrial and cognitive dysfunction, which occurred at 4-5 months old mice [10]. These results are consistent with our observation that $\mathrm{mA \beta PP} / \mathrm{ABAD}$ mice at 5 (not 12) months of age had a significant decreased PreP activity in brain mitochondria compared to $\mathrm{mA} \beta \mathrm{PP}$ mitochondria. The results generated from 12 months old mice could be due to mouse model used in our study. Because 12 months old mA $\beta P P$ mice are the end stage of amyloid pathology together with abnormalities in mitochondrial and neuronal function, overexpression of ABAD in $\mathrm{mA \beta PP}$ mice might not further exaggerate $A \beta$-mediated deficits in mitochon- 
A

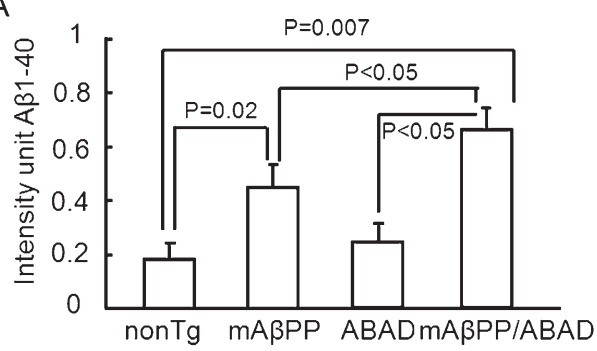

B

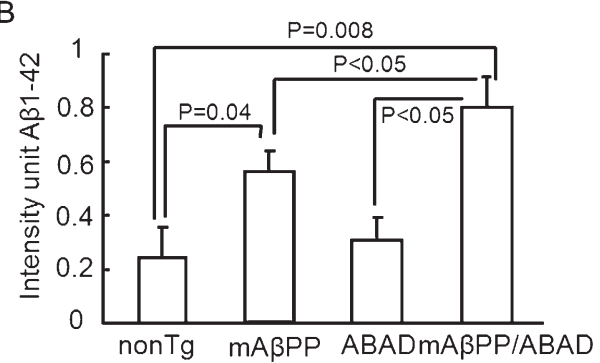

C

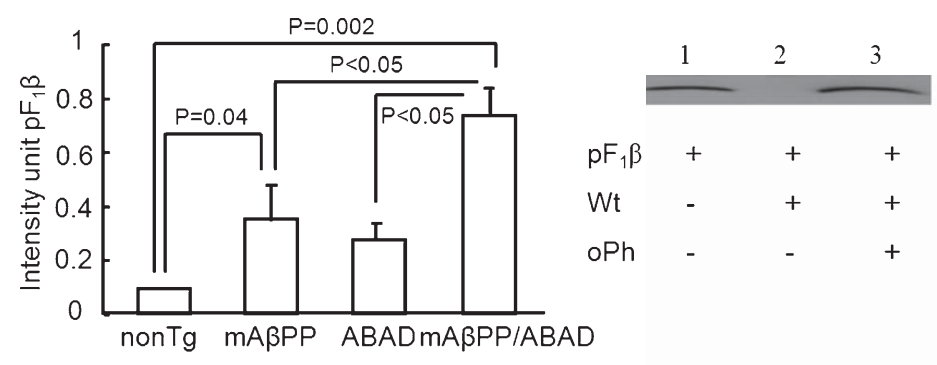

E

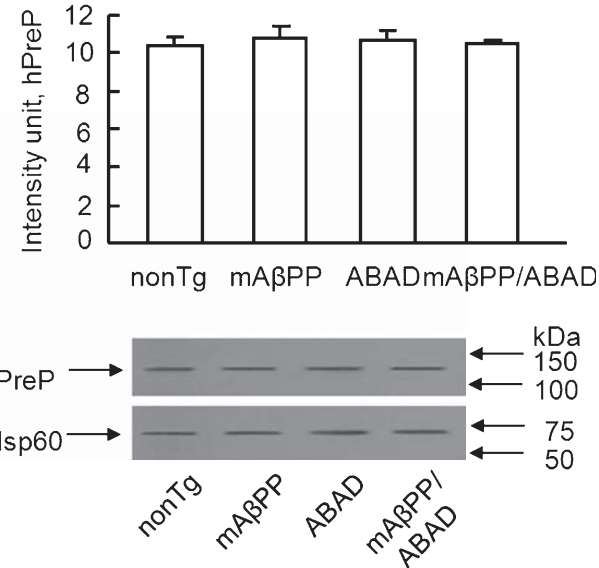

Fig. 3. Alterations of PreP activity/expression in transgenic $\mathrm{AD}$ mice. Cortical mitochondrial PreP extracted from 5-month-old indicated Tg mice degraded the biotin $A \beta_{40}(A), A \beta_{42}(B)$, and $\mathrm{pF}_{1} \beta(C)$, respectively. Densitometry of $A \beta_{40 / 42}$ or $\mathrm{pF}_{1} \beta$ immunoreactive bands was performed using NIH image program. The upper panels indicate the representative immunoblots for $\mathrm{A} \beta(\mathrm{A}, \mathrm{B})$ and $\mathrm{pF} \mathrm{F}_{1} \beta(\mathrm{D})$. In the presence of oPh, mitochondrial PreP was not able to degrade $\mathrm{pF}_{1} \beta$ peptide (lane 3 vs. lane 2). E) Immunoblotting of cortical mitochondrial protein from the indicated Tg mice for PreP. Representative immunoblots for PreP and Hsp60 are shown in the upper panel. Hsp60 (mitochondrial marker) was used as protein loading control and mitochondrial rich fractions. $n=4-7$ mice per group. All experiments were performed in triplicates.

drial and neuronal properties. To determine whether decreased PreP activity was due to alteration in PreP expression, mitochondrial proteins extracted from $\mathrm{Tg}$ mice were subjected to the immunoblotting with the specific antibody to PreP. Similar levels of PreP protein were expressed in all groups of Tg mice (Fig. 3E and $4 \mathrm{D}, p>0.05)$. To determine whether the alterations in PreP activity occurred before accumulation of mitochondrial $\mathrm{A} \beta$, we measured PreP activity in 2 months old cortical mitochondria. There were no significant differences of PreP activity between mA $\beta P P$ cortical mitochondria and nonTg cortical mitochondria at the age of 2 month prior to detectable mitochondrial $A \beta$ accumulation (data not shown).

When comparing the activity of PreP in five-months and twelve-months-old nonTg, and Tg mA $\beta P P$ mice, we found that proteolytic activity decreased in an agedependent manner (Fig. 5A-C). There was a significant difference in the capacity of PreP to degrade $\mathrm{pF}_{1} \beta$ in five-months-old nonTg and Tg mAßPP mice compared to twelve-months old mice (Fig. 5 C). A probable explanation for these observations may be the effect of aging. Interestingly, when comparing the proteolytic activity of PreP in five-months and twelve-months-old Tg mAßPP mice, a significant difference was noted in degradation against all three peptides, possibly due to overproduction of $\mathrm{mA} \beta \mathrm{PP}$ and consequently elevated $A \beta$ generation and accumulation that enhances the effect of aging thereby affecting PreP activity.

\section{Mitochondrial oxidative stress and mitochondrial dysfunction in A $\beta$-rich mitochondria}

In light of elevated levels of oxidative stress in the $\mathrm{AD}$ brain and $\mathrm{A} \beta$-rich mitochondria, and the potential effects of oxidative stress on PreP activity, we measured HNE levels, an oxidative stress marker, in the mitochondrial fractions used in the present studies. As shown in Fig. 6, HNE levels were significantly elevated in the $\mathrm{AD}$ temporal lobe mitochondria compared with non-AD mitochondria (Fig. 6A), while levels of $\mathrm{HNE}$ in cerebellum mitochondria were comparable 
A

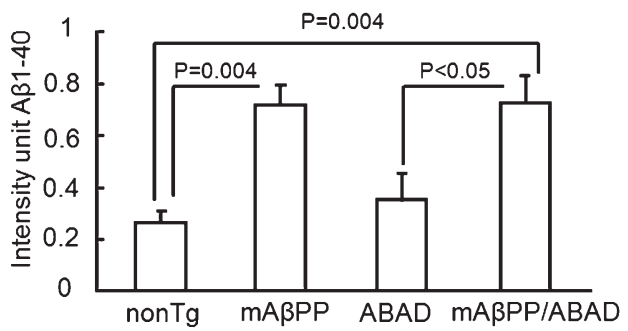

C

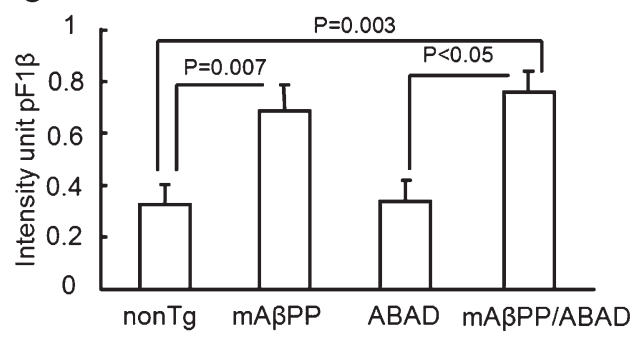

B

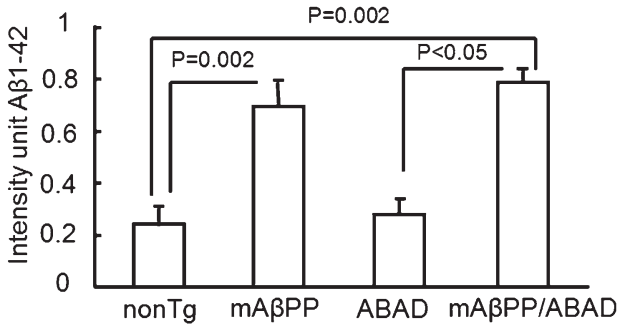

D
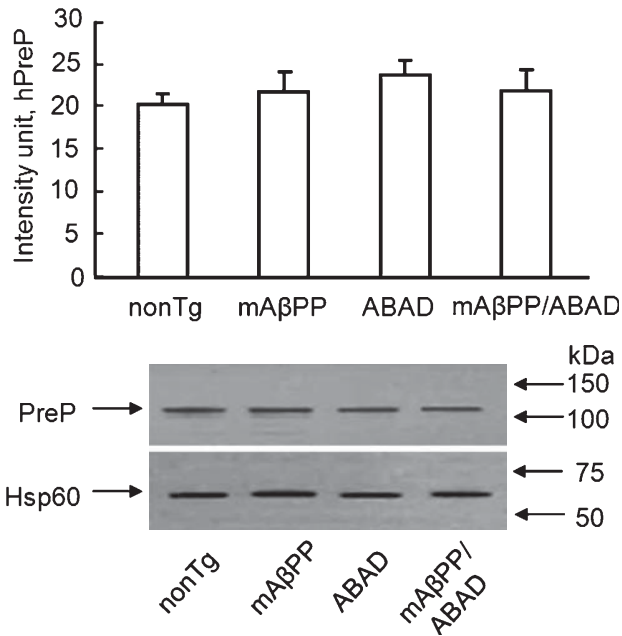

Fig. 4. PreP activity/expression in $\mathrm{Tg} \mathrm{AD}$ mice at age of twelve months. The cortical mitochondrial PreP from twelve-months-old Tg mice degraded biotin $A \beta_{40 / 42}(\mathrm{~A}, \mathrm{~B})$ and $\mathrm{pF}_{1} \beta(\mathrm{C})$ Densitometry of combined immunoreactive bands $\left(\mathrm{A} \beta\right.$ or $\left.\mathrm{pF} \mathrm{F}_{1} \beta\right)$ from the indicated Tg mice. D) Immunoblotting of mitochondrial fractions from the indicated Tg mice for PreP or Hsp60. $n=4-5$ mice per group. All experiments were performed in triplicates.
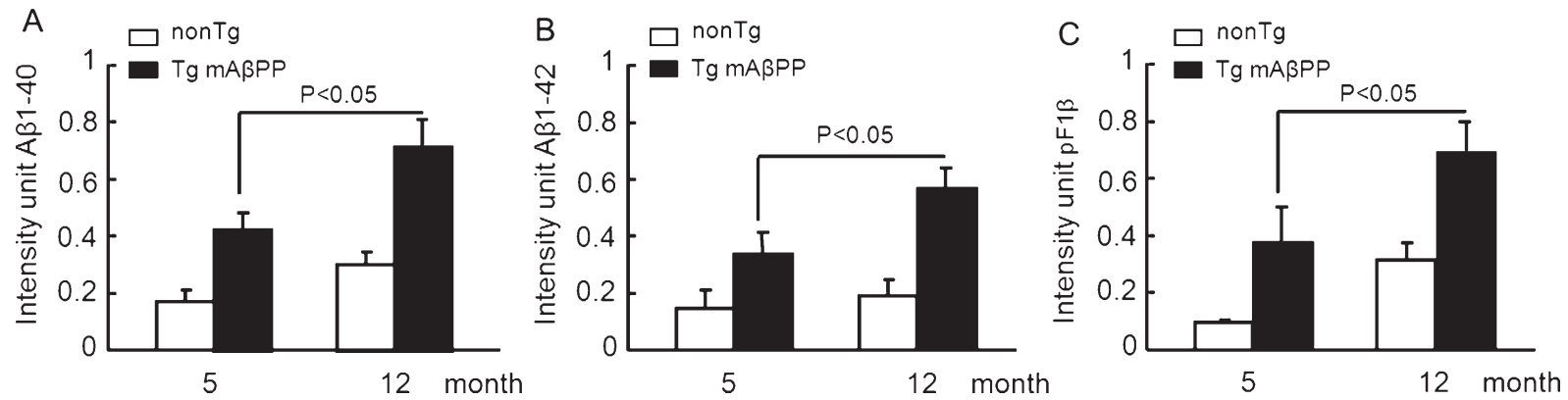

Fig. 5. Age-dependent decreased PreP activity in Tg mAßPP mice. Cortical mitochondrial PreP was extracted from Tg $\mathrm{mA} \beta \mathrm{PP}$ and nonTg mice at ages of five and twelve months, and then incubated with biotin $A \beta_{40 / 42}(A, B)$ and $\mathrm{pF}_{1} \beta(\mathrm{C})$, respectively. Densitomery of all immunoreactive bands for $A \beta$ and $\mathrm{pF}_{1} \beta$ is shown. $n=4-6$ mice per group. All experiments were performed in triplicates.

between AD and non-AD (Fig. 6B). Similarly, HNE levels were significantly higher in $\mathrm{mA} \beta \mathrm{PP}$ mitochondria than in nonTg mitochondria. The $\mathrm{mA} \beta \mathrm{PP} / \mathrm{ABAD}$ mitochondria exhibited increased HNE levels compared to $\mathrm{mA} \beta \mathrm{PP}$ mitochondria (Fig. 6C) as early as five months old. These results are consistent with our previous observation that overexpressed ABAD in $\mathrm{Tg}$ $\mathrm{mA} \beta P P$ mice enhanced generation of reactive free radicals [10].

Next, we measured the activity of cytochrome c oxidase, a key respiratory enzyme, in human brain mitochondria to determine the correlation of mitochon- 
A

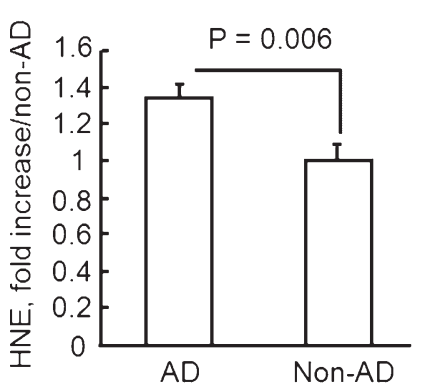

D

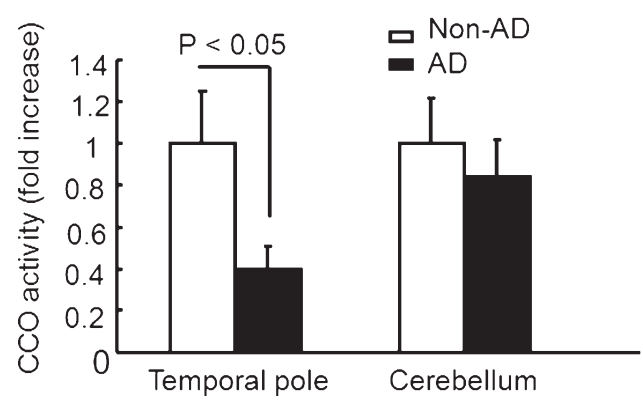

B

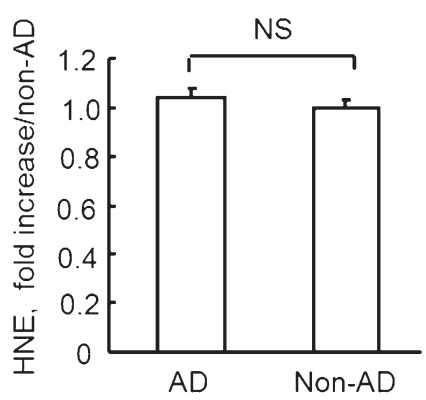

$A \beta(1-40)$

Mit matrix

$\mathrm{K}_{3} \mathrm{Fe}(\mathrm{CN})_{6}(\mathrm{mM})$
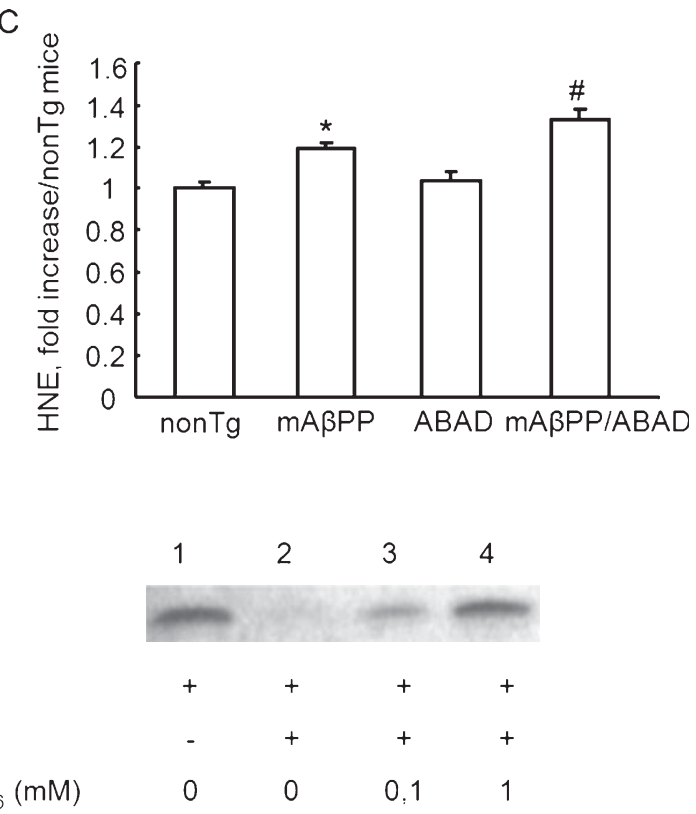

Fig. 6. A. HNE levels and cytochrome c oxidase activity in brain mitochondria. HNE levels in cortical mitochondria isolated from temporal lobe (A) and cerebellum (B) of AD and non-AD brains were measured by ELISA. $n=10-11$ mice per group. C) HNE levels in cortical mitochondria from the indicated Tg mice were determined by ELISA. ${ }^{*} p<0.05$ vs. nonTg mice, $\# p<0.05$ vs. nonTg and mA $3 P P$ mice. $n=8-9$ mice per group. D) Cytochrome c oxidase activity in cortical mitochondria from temporal lobe and cerebellum of AD and non-AD subjects. E) Decreased hPreP activity in mitochondrial matrix in the presence of $0.1 \mathrm{mM}$ and $1 \mathrm{mM} \mathrm{K} 3 \mathrm{Fe}(\mathrm{CN})_{6}$ (lanes 3 and 4).

drial function to the alterations in PreP. Cytochrome c oxidase activity was significantly decreased in cortical mitochondria from AD temporal lobe ( 50-60\% lower than non-AD mitochondria); but only a small change in cytochrome c oxidase activity ( $10 \%$ change) was noted in cerebellum mitochondria when comparing $\mathrm{AD}$ and non-AD brains (Fig. 6D). These studies suggest that aberrant mitochondrial function from $A \beta$-rich mitochondria of AD-affected brain correlates to alterations in PreP proteolytic activity.

We have also investigated PreP activity against $A \beta_{1-40}$ in the mitochondrial matrix under oxidized conditions, in the presence of increasing concentrations of $\mathrm{K}_{3} \mathrm{Fe}(\mathrm{CN})_{6}$. PreP activity was completely inhibited at $1 \mathrm{mM} \mathrm{K}{ }_{3} \mathrm{Fe}(\mathrm{CN})_{6}$ (Fig. 6E). This is in agreement with our previous results [27], in which we have shown that degradation of $A \beta_{1-40}$ with recombinant hPreP was totally reduced under oxidized conditions.

\section{DISCUSSION}

Several lines of evidence suggest that steady-state levels of $\mathrm{A} \beta$, a fundamental feature of $\mathrm{AD}$, are achieved by a balance between $A \beta$ generation and clearance and that disruption of the clearance system gives rise to increased $A \beta$ accumulation. Several proteases have recently been shown to be involved in regulation of the steady-state level of A $\beta$ including IDE, a cytoplasmic functional analogue of hPreP, and neprilysine (NEP), a plasma membrane-anchored zinc metallprotease. Both have been extensively studied and are implicated in AD [39-41]. Several reports emphasize the potentially important role of mitochondrial dysfunction and elevated ROS production in $\mathrm{AD}$ development $[10,12$, $26,42-44]$. A $\beta$ accumulation in this vital organelle has been reported to occur in brain mitochondria of $\mathrm{AD}$ transgenic mice models prior to the extracellular $\mathrm{A} \beta$ deposits and to cause increases in ROS production $[10,26]$. Elevated levels of oxidative stress have also been observed in $A \beta$-affected areas in postmortem $A D$ brains [8]. We have identified PreP as the novel $A \beta$ degrading protease in human brain mitochondria [27].

In the present studies, we show that hPreP proteolytic activity is reduced in the AD-affected region, temporal lobe, while similar results were not observed in the AD-spared cerebellum, a region often free of $\mathrm{A} \beta$ accumulation. Proteolytic activity of hPreP in 
mitochondrial matrix isolated from temporal lobe of $\mathrm{AD}$ patients and non-AD age-matched controls was measured with three different peptides (biotin labeled $\mathrm{A} \beta_{1-40}$, biotin labeled $\mathrm{A} \beta_{1-42}$, and $\left.\mathrm{pF}_{1} \beta\right)$ using an in vitro degradation assay; further, hPreP activity in isolated cerebellum mitochondrial matrix of $\mathrm{AD}$ individuals was compared to age-matched controls. A significant reduction in PreP function was also confirmed in $\mathrm{AD}$ transgenic mice models (Tg mAßPP and $\mathrm{Tg} \mathrm{mA} \beta \mathrm{PP} / \mathrm{ABAD}$ ) compared to nonTg mice using the above listed peptides as substrates. Biotin labeled $A \beta$ in the degradation assays was used to distinguish it from the $A \beta$ accumulated in $A D$ brain mitochondria and transgenic mice models. $\mathrm{pF}_{1} \beta$, a 53 amino acid long mitochondrial presequence peptide, was used as a non- $\mathrm{A} \beta$ substrate to further determine PreP proteolytic activity. Although these peptides have slightly different properties (as $A \beta$ peptides are negatively charged, whereas $\mathrm{pF}_{1} \beta$ is positively charged), hPreP degraded these substrates with similar efficiency. Importantly, $A \beta$-containing mitochondria from $A D, m A \beta P P$, or $\mathrm{mA} \beta P P / A B A D$ brains showed significantly decreased PreP proteolytic activity for degrading both $\mathrm{A} \beta$ and non- $\mathrm{A} \beta$ substrates. Accordingly, mitochondrial respiratory function was also reduced in these $\mathrm{AD}$ mitochondria as well as in $\mathrm{mA} \beta \mathrm{PP}$ or $\mathrm{mA} \beta \mathrm{PP} / \mathrm{ABAD}$ mitochondria $[8,9,12,13,26]$. The strong negative correlation between PreP activity and mitochondrial $A \beta$ accumulation suggests that functional PreP is important for maintenance of mitochondrial function through its capabilities to detoxify and to clear mitochondrial $A \beta$.

hPreP is a metalloprotease that is able to degrade mitochondrial presequences after they have been cleaved off from precursor proteins as well as other unstructured peptides in the range of 10 to 70 amino acid residues. We have previously reported that recombinant $\mathrm{hPreP}$ degraded both the mitochondrial presequence $\mathrm{pF}_{1} \beta$ as well as $A \beta_{1-40}, A \beta_{1-42}$, and $A \beta$ Arctic (E22G) peptides [26]. Here, we demonstrate that hPreP is also able to degrade $A \beta_{40-1}$. This finding is not surprising as PreP is a general peptidasome with a preference for positively charged amino acids in the $\mathrm{P}_{1}^{\prime}$ position and small-uncharged residues or serine residues in the $\mathrm{P}_{1}$ position and it does not exhibit any unique cleavage specificity [33]. Most importantly, under physiological and pathological conditions such as $A D$, reversed $A \beta_{40-1}$ peptide is not present in both human and mouse brains, which is not relevant to human disease.

Since no change was observed in the protein expression level of hPreP in $\mathrm{AD}$ cases versus non-AD individuals or in the $\mathrm{AD}$ transgenic mice models versus nonTg mice, the reduced proteolytic ability of PreP is most probably due to AD-related PreP functional alteration. When comparing the gene expression levels in the brain of $\mathrm{A} \beta \mathrm{PP}$ overexpressing mice of different ages to age-matched nonTg mice, Reddy et al. [45] observed a consistent increase of mRNA corresponding to proteins involved in mitochondrial energy metabolism and apoptosis, but they did not report any change in the mRNA levels of PreP, which is in agreement with our protein expression data. hPreP contains two cysteines situated close to each other. Under oxidized conditions these cysteines form a disulphide bridge locking the two protein halves of the enzyme in a closed conformation generating an inactive PreP [27]. These cysteines are conserved in all mammalian homologues of PreP. Measurement of the proteolytic activity of hPreP in the presence of an oxidizing $\mathrm{K}_{3} \mathrm{Fe}$ $(\mathrm{CN})_{6}$ shows complete inhibition. Reduction of hPreP proteolytic activity observed in $\mathrm{AD}$-affected areas of brain may thus be due to formation of the disulphide bridge that occurs because of the elevated ROS formation (that occurs in the vulnerable regions of $\mathrm{AD}$ brain). However, attempts to reactivate the enzyme by pre-incubating isolated matrix fraction with DTT, a reducing agent, revealed inconsistent results indicating that other factors, such as amino acid modification rather than disulphide bond formation may be responsible for inactivation of the enzyme.

Notably, PreP activity was significantly diminished in the $A \beta$-enriched mitochondria as compared with the nonTg mitochondria, suggesting the association of mitochondrial $A \beta$ with alterations in PreP activity. Indeed, our recent study indicates that increased PreP activity in Tg mA $\beta P P$ mice significantly reduced mitochondrial A $\beta$ accumulation [51] Furthermore, our data also revealed an age-related reduction of PreP function in transgenic mice models, which suggests that the PreP activity may decrease during aging.

In summary, our data clearly demonstrate that PreP proteolytic activity was significantly reduced in $A \beta-$ enriched mitochondria such as in AD-affected brains and AD mouse models. Levels of PreP activity negatively correlate to mitochondrial oxidative stress and positively associate with mitochondrial respiratory function. Deficits in PreP proteolytic activity observed in $\mathrm{AD}$ brain may be a significant contributing factor leading to cerebral $\mathrm{A} \beta$ accumulation, which in turn results in mitochondrial dysfunction. For future areas of investigation, it will be important to elucidate the mechanisms underlying reduced PreP function in 
AD-affected regions of the brain. The current data provides important evidence for $\mathrm{AD}$ - and age-related alterations of this mitochondrial $\mathrm{A} \beta$-degrading protease, and may open avenues to new pharmacological approaches or gene therapy to upregulate PreP activity or increase PreP levels that will enhance $A \beta$ clearance in mitochondria and thereby halt disease progression.

\section{ACKNOWLEDGMENTS}

This work was supported by grants from the USPHS (P01AG17490, AG037319, and AG040011), Alzheimer's Association, The Swedish Research Council (M2005-4831, NT-2006-4393), Lennanders Foundation and Fundacao para a Ciência e a Tecnologia, Portugal, through PhD fellowship SFRH/BD/ 60783/2009.

Authors' disclosures available online (http://www.jalz.com/disclosures/view.php?id=890).

\section{REFERENCES}

[1] Kimberly WT, LaVoie MJ, Ostaszewski BL, Ye W, Wolfe MS, Selkoe DJ (2003) Gamma-secretase is a membrane protein complex comprised of presenilin, nicastrin, Aph-1, and Pen-2. Proc Natl Acad Sci U S A 100, 6382-6387.

[2] Selkoe DJ (1999) Translating cell biology into therapeutic advances in Alzheimer's disease. Nature 399, A23-A31.

[3] Masters CL, Simms G, Weinman NA, Multhaup G, McDonald BL, Beyreuther K (1985) Amyloid plaque core protein in Alzheimer disease and Down syndrome. Proc Natl Acad Sci U S A 82, 4245-4249.

[4] Soderberg L, Bogdanovic N, Axelsson B, Winblad B, Naslund J, Tjernberg LO (2006) Analysis of single Alzheimer solid plaque cores by laser capture microscopy and nanoelectrospray/tandem mass spectrometry. Biochemistry 45, 9849-9856.

[5] Gouras GK, Almeida CG, Takahashi RH (2005) Intraneuronal Abeta accumulation and origin of plaques in Alzheimer's disease. Neurobiol Aging 26, 1235-1244.

[6] Wang X, Su B, Perry G, Smith MA, Zhu X (2007) Insights into amyloid-beta-induced mitochondrial dysfunction in Alzheimer disease. Free Radic Biol Med 43, 1569-1573.

[7] Wirths O, Multhaup G, Bayer TA (2004) A modified betaamyloid hypothesis: intraneuronal accumulation of the betaamyloid peptide-the first step of a fatal cascade. J Neurochem 91, 513-520.

[8] Caspersen C, Wang N, Yao J, Sosunov A, Chen X, Lustbader JW, Xu HW, Stern D, McKhann G, Yan SD (2005) Mitochondrial Abeta: a potential focal point for neuronal metabolic dysfunction in Alzheimer's disease. FASEB J 19, 2040-2041.

[9] Du H, Yan S, Sosunov AA, Mckhann GM, Yan SS (2010) Early deficits in synaptic mitochondria in an Alzheimer's disease mouse model. Proc Natl Acad Sci U S A 107(43):18670-18675

[10] Lustbader JW, Cirilli M, Lin C, Xu HW, Takuma K, Wang N, Caspersen C, Chen X, Pollak S, Chaney M, Trinchese F, Liu S, Gunn-Moore F, Lue LF, Walker DG, Kuppusamy P,
Zewier ZL, Arancio O, Stern D, Yan SS, Wu H (2004) ABAD directly links Abeta to mitochondrial toxicity in Alzheimer's disease. Science 304, 448-452.

[11] Manczak M, Anekonda TS, Henson E, Park BS, Quinn J, Reddy PH (2006) Mitochondria are a direct site of A beta accumulation in Alzheimer's disease neurons: implications for free radical generation and oxidative damage in disease progression. Hum Mol Genet 15, 1437-1449.

[12] Du H, Guo L, Fang F, Chen D, Sosunov AA, McKhann GM, Yan Y, Wang C, Zhang H, Molkentin JD, Gunn-Moore FJ, Vonsattel JP, Arancio O, Chen JX, Yan SD (2008) Cyclophilin D deficiency attenuates mitochondrial and neuronal perturbation and ameliorates learning and memory in Alzheimer's disease. Nat Med 14, 1097-1105.

[13] Du H, Guo L, Zhang W, Rydzewska M, Yan S (2011) Cyclophilin D deficiency improves mitochondrial function and learning/memory in aging Alzheimer disease mouse model. Neurobiol Aging 32, 398-406.

[14] Hansson Petersen CA, Alikhani N, Behbahani H, Wiehager B, Pavlov PF, Alafuzoff I, Leinonen V, Ito A, Winblad B, Glaser E, Ankarcrona M (2008) The amyloid beta-peptide is imported into mitochondria via the TOM import machinery and localized to mitochondrial cristae. Proc Natl Acad Sci U S A 105, 13145-13150.

[15] Yao J, Irwin RW, Zhao L, Nilsen J, Hamilton RT, Brinton RD (2009) Mitochondrial bioenergetic deficit precedes Alzheimer's pathology in female mouse model of Alzheimer's disease. Proc Natl Acad Sci U S A 106, 14670-14675.

[16] Eckert A, Hauptmann S, Scherping I, Meinhardt J, Rhein V, Drose S, Brandt U, Fandrich M, Muller WE, Gotz J (2008) Oligomeric and fibrillar species of beta-amyloid (A beta 42) both impair mitochondrial function in P301L tau transgenic mice. J Mol Med 86, 1255-1267.

[17] Eckert A, Hauptmann S, Scherping I, Rhein V, Muller-Spahn F, Gotz J, Muller WE (2008) Soluble beta-amyloid leads to mitochondrial defects in amyloid precursor protein and tau transgenic mice. Neurodegener Dis 5, 157-159.

[18] Anandatheerthavarada HK, Biswas G, Robin MA, Avadhani NG (2003) Mitochondrial targeting and a novel transmembrane arrest of Alzheimer's amyloid precursor protein impairs mitochondrial function in neuronal cells. J Cell Biol 161, 41-54.

[19] Devi L, Prabhu BM, Galati DF, Avadhani NG, Anandatheerthavarada HK (2006) Accumulation of amyloid precursor protein in the mitochondrial import channels of human Alzheimer's disease brain is associated with mitochondrial dysfunction. J Neurosci 26, 9057-9068.

[20] Pavlov PF, Wiehager B, Sakai J, Frykman S, Behbahani H, Winblad B, Ankarcrona M (2011) Mitochondrial gammasecretase participates in the metabolism of mitochondriaassociated amyloid precursor protein. FASEB J 25, 78-88.

[21] Takuma K, Fang F, Zhang W, Yan S, Fukuzaki E, Du H, Sosunov A, McKhann G, Funatsu Y, Nakamichi N, Nagai T, Mizoguchi H, Ibi D, Hori O, Ogawa S, Stern DM, Yamada K, Yan SS (2009) RAGE-mediated signaling contributes to intraneuronal transport of amyloid-beta and neuronal dysfunction. Proc Natl Acad Sci U S A 106, 20021-20026.

[22] He XY, Wen GY, Merz G, Lin D, Yang YZ, Mehta P, Schulz H, Yang SY (2002) Abundant type 1017 beta-hydroxysteroid dehydrogenase in the hippocampus of mouse Alzheimer's disease model. Brain Res Mol Brain Res 99, 46-53.

[23] Chen JX, Yan SD (2007) Amyloid-beta-induced mitochondrial dysfunction. J Alzheimers Dis 12, 177-184.

[24] Yao J, Taylor M, Davey F, Ren Y, Aiton J, Coote P, Fang F, Chen JX, Yan SD, Gunn-Moore FJ (2007) Interaction of 
amyloid binding alcohol dehydrogenase/Abeta mediates upregulation of peroxiredoxin II in the brains of Alzheimer's disease patients and a transgenic Alzheimer's disease mouse model. Mol Cell Neurosci 35, 377-382.

[25] Ren Y, Xu HW, Davey F, Taylor M, Aiton J, Coote P, Fang F, Yao J, Chen D, Chen JX, Yan SD, Gunn-Moore FJ (2008) Endophilin I expression is increased in the brains of Alzheimer disease patients. J Biol Chem 283, 5685-5691.

[26] Takuma K, Yao J, Huang J, Xu H, Chen X, Luddy J, Trillat AC, Stern DM, Arancio O, Yan SS (2005) ABAD enhances Abetainduced cell stress via mitochondrial dysfunction. FASEB $J$ 19, 597-598.

[27] Falkevall A, Alikhani N, Bhushan S, Pavlov PF, Busch K, Johnson KA, Eneqvist T, Tjernberg L, Ankarcrona M, Glaser E (2006) Degradation of the amyloid beta-protein by the novel mitochondrial peptidasome, PreP. J Biol Chem 281, 2909629104.

[28] Alikhani N, Ankarcrona M, Glaser E (2009) Mitochondria and Alzheimer's disease: amyloid-beta peptide uptake and degradation by the presequence protease, hPreP. J Bioenerg Biomembr 41, 447-451.

[29] Farris W, Mansourian S, Chang Y, Lindsley L, Eckman EA, Frosch MP, Eckman CB, Tanzi RE, Selkoe DJ, Guenette $S$ (2003) Insulin-degrading enzyme regulates the levels of insulin, amyloid beta-protein, and the beta-amyloid precursor protein intracellular domain in vivo. Proc Natl Acad Sci U S A 100, 4162-4167.

[30] Miller BC, Eckman EA, Sambamurti K, Dobbs N, Chow KM, Eckman CB, Hersh LB, Thiele DL (2003) Amyloid-beta peptide levels in brain are inversely correlated with insulysin activity levels in vivo. Proc Natl Acad Sci U S A 100, 62216226.

[31] Tanzi RE, Moir RD, Wagner SL (2004) Clearance of Alzheimer's Abeta peptide: the many roads to perdition. $\mathrm{Neu}$ ron 43, 605-608.

[32] Stahl A, Moberg P, Ytterberg J, Panfilov O, Brockenhuus Von Lowenhielm H, Nilsson F, Glaser E (2002) Isolation and identification of a novel mitochondrial metalloprotease (PreP) that degrades targeting presequences in plants. J Biol Chem $\mathbf{2 7 7}$, 41931-41939.

[33] Stahl A, Nilsson S, Lundberg P, Bhushan S, Biverstahl H, Moberg P, Morisset M, Vener A, Maler L, Langel U, Glaser E (2005) Two novel targeting peptide degrading proteases, PrePs, in mitochondria and chloroplasts, so similar and still different. J Mol Biol 349, 847-860.

[34] Glaser E, Alikhani N (2010) The organellar peptidasome, PreP: a journey from Arabidopsis to Alzheimer's disease. Biochim Biophys Acta 1797, 1076-1080.

[35] Johnson KA, Bhushan S, Stahl A, Hallberg BM, Frohn A, Glaser E, Eneqvist T (2006) The closed structure of presequence protease PreP forms a unique 10,000 Angstroms3 chamber for proteolysis. EMBO J 25, 1977-1986.

[36] Moberg P, Nilsson S, Stahl A, Eriksson AC, Glaser E, Maler L (2004) NMR solution structure of the mitochondrial F1beta presequence from Nicotiana plumbaginifolia. J Mol Biol 336, 1129-1140.

[37] Mucke L, Masliah E, Yu GQ, Mallory M, Rockenstein EM, Tatsuno G, Hu K, Kholodenko D, Johnson-Wood K, McConlogue L (2000) High-level neuronal expression of abeta 1-42 in wild-type human amyloid protein precursor transgenic mice: synaptotoxicity without plaque formation. J Neurosci 20, 4050-4058.

[38] Arancio O, Zhang HP, Chen X, Lin C, Trinchese F, Puzzo D, Liu S, Hegde A, Yan SF, Stern A, Luddy JS, Lue LF,
Walker DG, Roher A, Buttini M, Mucke L, Li W, Schmidt AM, Kindy M, Hyslop PA, Stern DM, Du Yan SS (2004) RAGE potentiates Abeta-induced perturbation of neuronal function in transgenic mice. EMBO J 23, 4096-4105.

[39] Iwata N, Tsubuki S, Takaki Y, Shirotani K, Lu B, Gerard NP, Gerard C, Hama E, Lee HJ, Saido TC (2001) Metabolic regulation of brain Abeta by neprilysin. Science 292, 15501552.

[40] Iwata N, Tsubuki S, Takaki Y, Watanabe K, Sekiguchi M, Hosoki E, Kawashima-Morishima M, Lee HJ, Hama E, Sekine-Aizawa Y, Saido TC (2000) Identification of the major Abeta1-42-degrading catabolic pathway in brain parenchyma: suppression leads to biochemical and pathological deposition. Nat Med 6, 143-150.

[41] Yasojima K, Akiyama H, McGeer EG, McGeer PL (2001) Reduced neprilysin in high plaque areas of Alzheimer brain: a possible relationship to deficient degradation of beta-amyloid peptide. Neurosci Lett 297, 97-100.

[42] Bulteau AL, Szweda LI, Friguet B (2006) Mitochondrial protein oxidation and degradation in response to oxidative stress and aging. Exp Gerontol 41, 653-657.

[43] Reddy PH, Beal MF (2005) Are mitochondria critical in the pathogenesis of Alzheimer's disease?. Brain Res Brain Res Rev 49, 618-632.

[44] Reddy PH, Beal MF (2008) Amyloid beta, mitochondrial dysfunction and synaptic damage: implications for cognitive decline in aging and Alzheimer's disease. Trends Mol Med 14, 45-53.

[45] Reddy PH, McWeeney S, Park BS, Manczak M, Gutala RV, Partovi D, Jung Y, Yau V, Searles R, Mori M, Quinn J (2004) Gene expression profiles of transcripts in amyloid precursor protein transgenic mice: up-regulation of mitochondrial metabolism and apoptotic genes is an early cellular change in Alzheimer's disease. Hum Mol Genet 13, 1225-1240.

[46] Butterfield DA, Lauderback CM (2002) Lipid peroxidation and protein oxidation in Alzheimer's disease brain: potential causes and consequences involving amyloid beta-peptideassociated free radical oxidative stress. Free Radic Biol Med 32, 1050-1060.

[47] Yan SD, Chen X, Schmidt AM, Brett J, Godman G, Zou YS, Scott CW, Caputo C, Frappier T, Smith MA et al. (1994) Glycated tau protein in Alzheimer disease: a mechanism for induction of oxidant stress. Proc Natl Acad Sci U S A 91, 7787-7791.

[48] Lauderback CM, Hackett JM, Huang FF, Keller JN, Szweda LI, Markesbery WR, Butterfield DA (2001) The glial glutamate transporter, GLT-1, is oxidatively modified by 4-hydroxy-2-nonenal in the Alzheimer's disease brain: the role of Abeta1-42. J Neurochem 78, 413-416.

[49] Caccamo A, Oddo S, Sugarman MC, Akbari Y, LaFerla FM (2005) Age- and region-dependent alterations in Abeta-degrading enzymes: implications for Abeta-induced disorders. Neurobiol Aging 26, 645-654.

[50] Wang DS, Iwata N, Hama E, Saido TC, Dickson DW (2003) Oxidized neprilysin in aging and Alzheimer's disease brains. Biochem Biophys Res Commun 310, 236-241.

[51] Yao J, Du H, Yan S, Fang F, Wang C, Lue LF, Guo L, Chen D, Stern DM, Gunn Moore FJ, Xi Chen J, Arancio O, Yan SS (2011) Inhibition of amyloid- $\beta$ (A $\beta$ ) peptide-binding alcohol dehydrogenase- $A \beta$ interaction reduces $A \beta$ accumulation and improves mitochondrial function in a mouse model of Alzheimer's disease. J Neurosci 31, 2313-2320. 
Copyright of Journal of Alzheimer's Disease is the property of IOS Press and its content may not be copied or emailed to multiple sites or posted to a listserv without the copyright holder's express written permission.

However, users may print, download, or email articles for individual use. 